research into civilian foreign affairs. It would like to see an inter-agency group, led by the State Department and including all the agencies which operate overseas, to plan long-term research objectives in the behavioural sciences. The chief responsibility for Government support for research in foreign countries should, however, remain in the hands of the National Science Foundation and the National Institutes of Health. The NSF is urged to give increasing emphasis to grants for behavioural seiences, but there is no means of knowing whether the NSF-with its budget cut already - will have to reduce still further its support for the conventional sciences.

The recommendation which has apparently generated most debate in the committee itself is that for the creation of an independently endowed National Institute for Advanced Research and Public Policy in Washington. The idea is that such an institute would "provide a kind of lightning rod for future changes as an alternative to the frustrating process of analysing social and economic crises after they have occurred and taken their toll". The committee is not, of course, under the misapprehension that behavioural scienceor anything else for that matter-is a substitute for wisdom and common sense in decision-making, but it is surely right in believing that civil servants ought at least to be familiar with the ways of behavioural scientists. No doubt American behavioural scientists themselves will be delighted by the report. Their British counterparts will be envious, not merely of the prospect of more to spend but because this report is yet another reminder of how the United States, to its credit and to everyone's advantage, has long recognized the value of a free flow between the universities and the Government.

\section{OIL POLLUTION No End of a Lesson}

A PaRLIamentary committee has now echoed public criticism of the handling of the Torrey Canyon disaster in March 1967. Last week on August 30, the House of Commons Select Committee on Science and Technology said of the disaster that "everyone concerned seems to have been caught unawares". The sense of unpreparedness seems to have been underlined by the evidence of Sir Solly Zuckerman, Chief Scientific Adviser to the British Government. By all accounts, four days went by before his advice was sought and he was unable to name a single minister responsible for putting his recommendations into effect. The investigation of what happened after the tanker went aground has been the responsibility of the Sub-Committee on Coastal Pollution under Sir Harry Legge-Bourke, MP. Understandably, its recommendations are to a large extent concerned with problems of government organization -for example, it asks that two ministers should jointly be given responsibility for preparing to deal with disasters of similar proportions and for the coordination and stimulation of research. There will no doubt be some disappointment and even surprise that the report names no scapegoats. The spirit of what it has to say is that of Kipling's couplet.
"Let us admit it fairly, as a business people should;

"We have had no end of a lesson: it will do us no end of good."

To give point to its fears about the future, the committee says that two oil tankers are involved in collisions every week and that one in ten of these results in spillage. The number and size of tankers are increasing rapidly-800 were added to the world's fleets in the past three years alone-and the risks of future accidents are plainly considerable. This is why, in the belief that prevention is better than cure, the committee asks that in future ships should not be allowed to carry oil to the United Kingdom unless they are equipped with VHF radio, echo sounders, radar and devices for radio position plotting. There is also a plea for further research into the possibility of forward underwater scanning equipment and automatic reversing devices, and the committee asks that oil carriers everywhere should adopt the "Ioad-on-top" system, first put into operation by Shell in 1961, in which oil not discharged from a cargo is kept on board and not dumped in the sea.

But how to clear up the mess when prevention has failed? The sub-committee has done its best to thread a course through the several suggestions for dealing with broken ships and spilt oil which have already been tried out or which might be on some future occasion. It sets much store by pumps for increasing the buoyancy of tankers and has been impressed by an experiment in which a pipe a foot in diameter was slung between a grounded tanker and another ship off the Bahamas in March this year. It has little enthusiasm for the use of detergents or materials which sink oil. Containment by means of booms and the firing of oil are limited in application. For the most part, the committee has lent its authority, enhanced by the thoroughness with which it has carried out its work, to a nine-point research programme which Sir Solly Zuckerman has put forward: 1. Means for speedy transfer of the cargo from a stranded tanker. 2. Methods of firing oil in stranded tankers and on the sea surface. 3. Effects of natural factors on the movement, dispersal and destruction of oil at sea. 4. Oil sinking, scavenging and gelling agents. 5. More effective but less toxic detergents. 6. Detergent spraying and other cleansing equipment. 7. Mechanical methods of removing oil both from the sea surface and from beaches. 8. Cheap and effective booms, primarily for protecting harbours and inlets. 9. Effects of pollution on marine life, seabirds and coastal vegetation and on ways of minimizing them. It will be interesting to see how much work has been done before the next tanker runs aground.

\section{INDUSTRY \\ Helium Prices Halved}

THe expanding industry of low temperature researchers has been pleased to see the price of liquid helium in Britain drop by almost half in five years. One of the factors underlying this reduction has been the challenge presented to the British Oxygen Company's monopoly position by Oxford Cryogenics, which was formed in 1963 by the directors of the Oxford Instrument Company. Oxford Cryogenics has now been taken over by the British subsidiary of Air Products and Chemicals Inc. 
For a few years from 1956, the only source of liquid helium in Britain was the National Physical Laboratory, which supplied it at $£ 5$ per litre. Growing demand led the NPL to encourage the British Oxygen Company (BOC) to take over the task of supplying helium but, despite the increasing market, BOC made little change to the price until Oxford Cryogenics entered the field. BOC has said that the high price was necessary to cover the costs of research and development-costs that Oxford Cryogenics, which entered a ready made market at a later stage, did not have to absorb.

Oxford Cryogenics has a different version of events. While paying full tribute to the present management of the BOC division concerned, it says that before 1963 liquid helium was so highly priced and difficult to obtain that there was a noticeable brake on the expansion of low temperature research in Britain. BOC did not deliver helium and customers had to arrange for their own supply by taxi and rail. Oxford Cryogenics began supply in 1963 with little more than a telephone and a second-hand delivery truck and within a few weeks had captured a substantial part of the market.

Since that time, prices of liquid helium have fallen

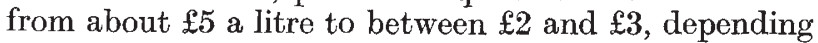
on quantity and other factors. Though competition is undoubtedly one factor in this reduction, the expansion of the market has also helped. So, too, has the acquisition by BOC of a share in a Canadian helium source. Previously the US Bureau of Mines had a near monopoly of helium.

Oxford Instruments is disposing of its liquid helium business because its primary purpose of making helium more readily available has been accomplished. The company's principal sphere of interest is in making apparatus for high magnetic fields and low temperatures. Serious trading began in 1963 and the company's turnover had passed $£ 250,000$ by 1967 .

\section{RAILWAYS \\ Transport Transported?}

The Museum of British Transport, part of the Railways Board and at present occupying what used to be a tram depot in Clapham High Street, London, may be moved to a new site in York. This recommendation. has been made after an investigation last year of the finances and management of British Rail and is just a small part of the policy to rid the railway of its deficit by 1971. The museum at Clapham houses a fine collection of rail and road relics and is one of three transport museums in Britain. The other two, at the railway centres of York and Swindon, are, strictly speaking, purely railway museums. Just now the three museums are run by the Railways Board, but the plan is to transfer the Swindon museum to Swindon Borough Council and to amalgamate the Clapham and York museums at York under the Department of Education and Science.

It is important to be clear just what this involves. The Clapham museum claims to have the largest collection of rail and road relics under one roof, including 13 locomotives and some 22 buses, trams and trolleybuses. The prize exhibit is obviously the magnificent streamlined locomotive "Mallard", built at Doncaster in 1938 and holder of the world speed record for steam traction. The museum also has on show other railway equipment, and a fascinating collection of royal coaches, including those used by Queen Victoria and by King Edward VII. On a smaller scale, all the paraphernalia of road and rail travel is there-the ticket machines, posters station signs and notices. To move the museum to York has some logic in the sense that it gathers together two of the important collections into a national museum, but it would mean that London then has no substantial exhibition of railway equipment.

The economics of the situation are that the Railways Board, in its efforts to improve its financial position, quite rightly feels it should no longer be saddled with the expense of running the three museums. The museum at Swindon is chiefly concerned with the history of the Great Western Railway and, as the development of Swindon is very much bound up with the development of the railway, it is sensible that the museum should be transferred to the borough council, which in any case already has much to do with running it. The York and Clapham museums are to come under the Department of Education and Sciencewhere they clearly belong-and will be combined as an out-station of the Science Museum.

Last year, visitors to the three museums totalled about 350,000 , and the gross revenue was $£ 48,000$. Like museums in general, the three transport museums
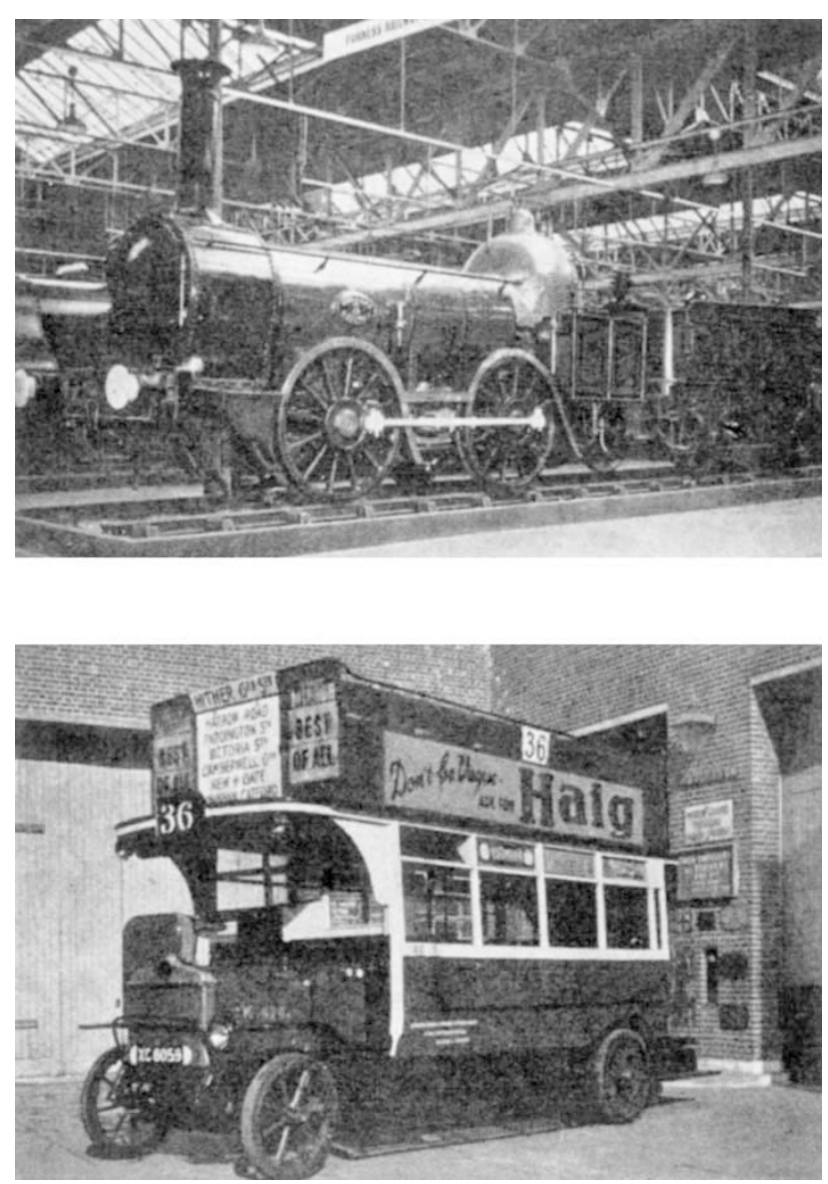

Two of the exhibits at Clapham. Locomotive No. 3 of the Furness Railway Co., delivered to the railway in 1849 and withdrawn from service in 1898; and a K-type omnibus of the London General Omnibus Co., 1919-the first design to have the driver seated beside the engine. 